\title{
Congenital Genitourinary Abnormality
}

National Cancer Institute

\section{Source}

National Cancer Institute. Congenital Genitourinary Abnormality. NCI Thesaurus. Code C35107.

An abnormality of the genitourinary system that is present at birth or detected in the neonatal period. 